\title{
Geology of the Structurally Controlled Quartz Vein Gold Mineralization in the Dikko Area, Part of Zungeru-Minna-Birnin Gwari Schist Belt, NW Nigeria
}

\author{
Abdullahi Adamu Mohammed1*, Adamu Usman Mohammed', Otorison Abdulganiu², \\ Danladi Abubakar Sadiq ${ }^{3}$ \\ ${ }^{1}$ Applied Geology Department, Abubakar Tafawa Balewa University, Bauchi, Nigeria \\ ${ }^{2}$ Geology Department (Engineering Services), Federal Capital Development Authority (FCDA), Abuja, Nigeria \\ ${ }^{3}$ Hadejia Jama'are River Basin Development Authority, Kano, Nigeria \\ Email: *adeebait@yahoo.co.uk
}

How to cite this paper: Mohammed, A. A., Mohammed, A. U., Abdulganiu, O., \& Sadiq, D. A. (2021). Geology of the Structurally Controlled Quartz Vein Gold Mineralization in the Dikko Area, Part of Zungeru-Minna-Birnin Gwari Schist Belt, NW Nigeria. Journal of Geoscience and Environment Protection, 9, 180-191. https://doi.org/10.4236/gep.2021.97012

Received: June 14, 2021

Accepted: July 25, 2021

Published: July 28, 2021

Copyright $\odot 2021$ by author(s) and Scientific Research Publishing Inc. This work is licensed under the Creative Commons Attribution International License (CC BY 4.0).

http://creativecommons.org/licenses/by/4.0/

\begin{abstract}
Dikko area, Niger State, North Central Nigeria falls within the Pan-African thermo-tectonic event which occurred in Nigeria as in other parts of West Africa with widespread effect on the mineralization of rejuvenated basement and geosynclinal trough deposits. The Pan-African Belt in Nigeria forms part of the Benin-Nigeria (Dahomeyan) shield which is regarded as the southern prolongation of the circumcratonic Pan-African belt of the West African Craton. Structurally controlled, gold-bearing quartz veins were measured and studied in the area from an extensive geological ground investigation. Field and petrographical studies indicate that the Neoproterozoic rocks constitute gneisses, amphibolite schist, amphibolites and migmatites. The amphibolites are intruded by pegmatites. The associated quartz veins are generally concordant with the main N-S regional structural trend. The lithological and structural studies carried out in these areas have demonstrated the relationship between structures and mineralization and/or lithology. The main characteristics of the gold mineralization in the area appear to indicate hydrothermal mineralization in connection with shear zones. This study allows us to predict that quartz veins in the amphibolite can be mined at a profit and a detailed geochemical and resource valuation needs to be carried out for the Au and associated Galena and Ag mineralization to fully exploit their economic potential.
\end{abstract}

\section{Keywords}

Gold, Mineralization, Quartz Veins, Pan-African, Economic Potential, Mined 


\section{Introduction}

The use of gold as an ornament and as money makes it a precious metal with the attendant rush for its exploration and exploitation worldwide. Considering the uncertainties also in the international market for Nigeria's major source of revenue (oil), there is that urgent necessity, therefore, to diversify the economy into other non-oil sectors which have been proven promising by many countries around the world. One of such sectors is the mineral resources, and of the many mineral potentials Nigeria has is Gold $(\mathrm{Au})$ which is considered the most sensuous metal, no precious metal is as legendary and beautiful as gold. Its rarity, beauty, and enigma have provided it with status as a valuable commodity throughout the history of humanity. Nevertheless, not much is known about the potentials of Nigeria's Gold belts, the Dikko area is one that has not received any attention.

The paucity of information regarding the emplacement of the Gold-bearing quartz veins is there and there is a general lack of geological data and inconsistencies for the host lithologies. The relationship between the different geological structures which may together control gold and gold-related mineralization/alteration zones is also lacking. There is also the issue concerning many parts of the schist belts where little geological information is available. One of such areas is the schist belt exposures around Dikko area, border between Suleja Local government from Northwestern Niger and areas around Kwakuti and Gedan, Southeastern border to Gurara Local Government of Niger State; this area geologically forms part of the Zungeru-Birnin Gwari Schist belt.

Turbidite-hosted mesothermal (orogenic) gold-bearing quartz veins have traditionally been assumed to have negligible wall rock alteration zones, but recent research has shown that these deposits typically have hydrothermal alteration haloes (e.g., Bierlein et al., 2000). Recognition of these alteration zones is important, as this increases the size of the target mineralized zone during mineral exploration (Osman \& Dardir, 1990; Bierlein et al., 2000). Thus, the volume of potential ore may be greater when alteration zones can be identified (Craw et al., 1999). This has led to the development of the concept of large tonnage, low-grade mesothermal gold deposits that include mineralized host rock as well as the narrow-mineralized quartz veins that have traditionally been the focus of mining (Mitchell et al., 2006). Osman (1995) used infrared absorption spectra and neutron activation analysis for the identification of similar alteration zones around gold-bearing quartz veins in the Eastern Desert of Egypt. Ramadan et al. (2001) used Landsat TM and SIR-C/X SAR imagery in mapping gold-bearing massive sulphide deposits in the Neoproterozoic Allaqi Suture, in southeastern Egypt. Other researchers (e.g., Kaufmann, 1988; Ramadan et al., 2001; Ramadan \& Kontny, 2004) used different remote sensing data to distinguish the mineralized alteration zones from the surrounding country rocks. Spectral variations associated with altered rocks caused by hydrothermal fluids are detected on Landsat TM images. Several authors studied the gold mineralization and the 
host rocks in Nigeria, e.g., Woakes and Bafor (1984) and Garba (2000, 2002, 2003). Garba (2003) suggested that the gold mineralization is present in alluvial and eluvial placers and primary veins from several parts of supracrustal (schist) belts in the northwest and southwest of Nigeria. He added that the most important occurrences are found in the Maru, Anka, Malele, Tsohon Birnin GwariKwaga, Gurmmana, Bin Yauri, Okolom-Dogondaji and Iperindo areas (Figure 1)

The schist belts (Figure 1) are low to medium grade deformed super crustal assemblages and have been intruded by Pan-African-syn to-late tectonic intrusions of granitoids (Abubakar, 2012).

The Pan-African terrane of northwestern Nigeria is part of the vast Late Proterozoic-Early Phanerozoic terrane separating the West African and Congo cratons. It consists of an older crust in which Archean (ca. $2700 \mathrm{Ma}$ ) and Early Proterozoic (ca. $2000 \mathrm{Ma}$ ) ages have been recorded (Grant et al., 1972), but were generally reactivated by the Pan-African event (Turner, 1983; Wright et al., 1985). The Pan-African event (600 $\pm 150 \mathrm{Ma})$ caused regional metamorphism, imposed a generally N-S foliation and brought about the emplacement of granitoids in the region (Turner, 1983). Wright et al. (1985) mentioned that a collision-type orogeny has been suggested by involving the Pan-African region and the West African craton, where a subduction zone dipped eastward beneath the Pan-African region. Deformation and metamorphism followed the continental collision around $660 \mathrm{Ma}$ ago with consequent crustal thickening in the Nigerian region.

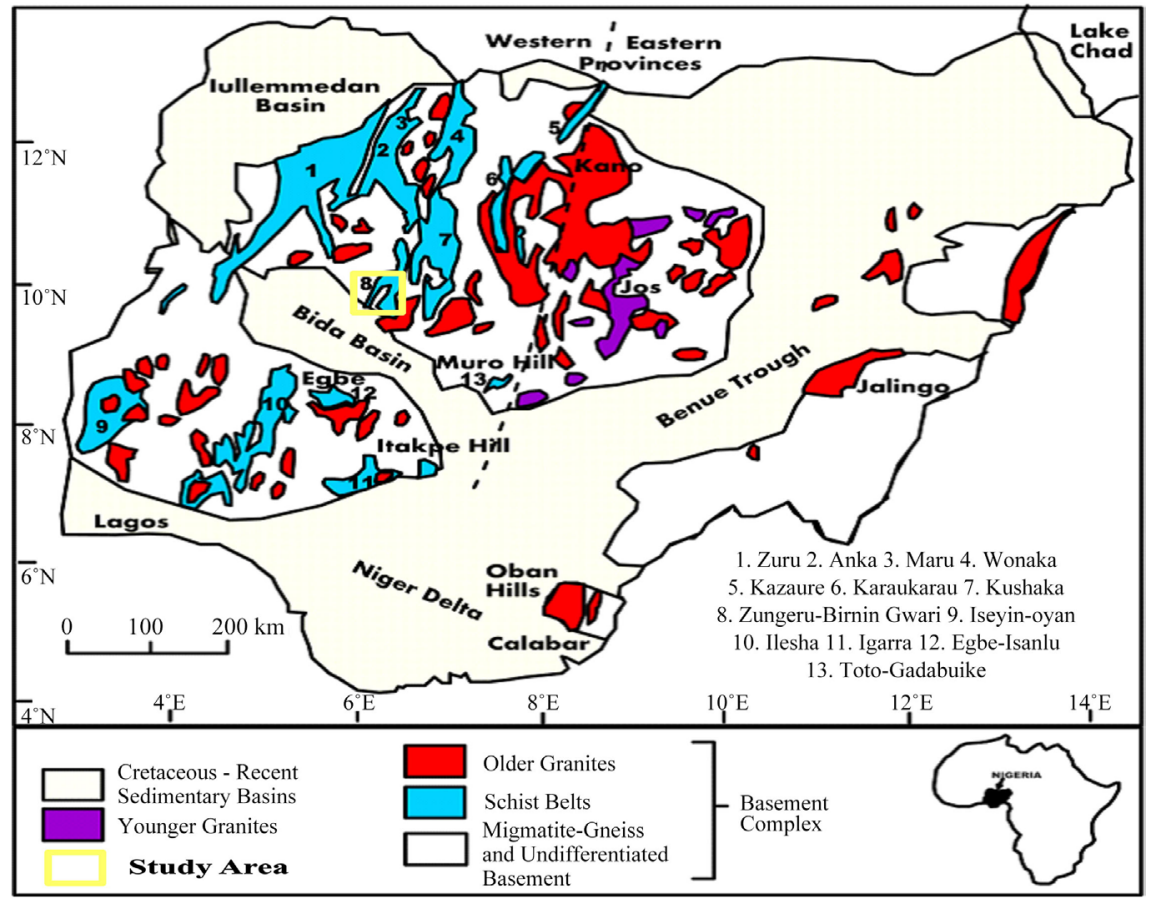

Figure 1. Schist Belt Localities within the context of the Geology of Nigeria, the yellow box insert; is the location of the study area (modified after Ajibade et al, 1987). 


\section{Geology of the Study Area}

The proposed study area falls between latitude $9^{\circ} 13^{\prime} 00^{\prime \prime} \mathrm{N}$ to $9^{\circ} 22^{\prime} 00^{\prime \prime} \mathrm{N}$ and longitude $7^{\circ} 00^{\prime} 00^{\prime \prime} \mathrm{E}$ to $7^{\circ} 11^{\prime} 15^{\prime \prime} \mathrm{E}$ which span an area of about $110 \mathrm{~km}^{2}$, geographically located along the border of Suleja Local Government Area of Niger State (Figure 2) Northcentral Nigeria. The study area geologically forms part of the Zungeru-Minna-Birnin Gwari Schist belt (Figure 1) which is one of the eleven Precambrian to early Paleozoic schist belts in Nigeria as documented by Turner (1983).

The general geology of Nigeria was given by several authors, e.g., Turner (1983), Wright et al. (1985), Ajibade and Wright (1989) and Garba (2003). Wright et al. (1985) gave a more general review and relating the evolution of Nigeria to other parts of West Africa.

The study area extents from the north-central to northwest Nigeria and it is mostly subdivided into three lithostratigraphic units: viz., the gneiss-migmatite complex, the supracrustal schist belts and the Pan African granitoids. The gneissmigmatite complex yielding Archean and Early-Proterozoic isotopic ages possesses generally an amphibolite facies grade of metamorphism (Fitches et al., 1985). They show complex structural styles and are extensively invaded by granitoid plutons of Pan-African magmatism. The schist belts of Late-Proterozoic age were deposited and metamorphosed together with the basement gneiss-migmatite complex during the Pan-African event. These belts contain assemblages of mafic igneous rocks, pelitic sediments and banded iron formation (BIF) and show complex structural styles. The belts trend N-S and NNE-SSW and were deformed and metamorphosed generally in the greenschist facies grade. The granitoids are mainly syn- to late-tectonic Pan-African intrusions of granites, granodiorites and diorites with some gabbros and syenites. They range in size from small sub-circular, crosscutting stocks to large elongate concordant batholithic bodies emplaced into both the gneiss-migmatites and supracrustal rocks during or just after the main phase of Pan-African deformation (Wright et al., 1985).

The area is characterized by some rock exposures, with elevations ranging between $420 \mathrm{~m}$ to about $630 \mathrm{~m}$ above sea level. The rocks of the area include amphibolite schist, amphibolites, gneisses, migmatites and pegmatites.

The area has a few networks of streams that appear to be ephemeral, which passes in between the hills and drains southwards into a river southward of Kwachife. The area is connected by several untarred roads and foot paths; it has no problem of accessibility.

\section{Methodology}

The method adopted in this work involved systematic surface mapping of outcrops, field observations, mapping and recording of structural features and collection of representative samples. Rock heterogeneity, quartz veining and gold mineralization guided the sampling. A total of 56 rocks samples with representative quartz veins samples were collected for this work. 


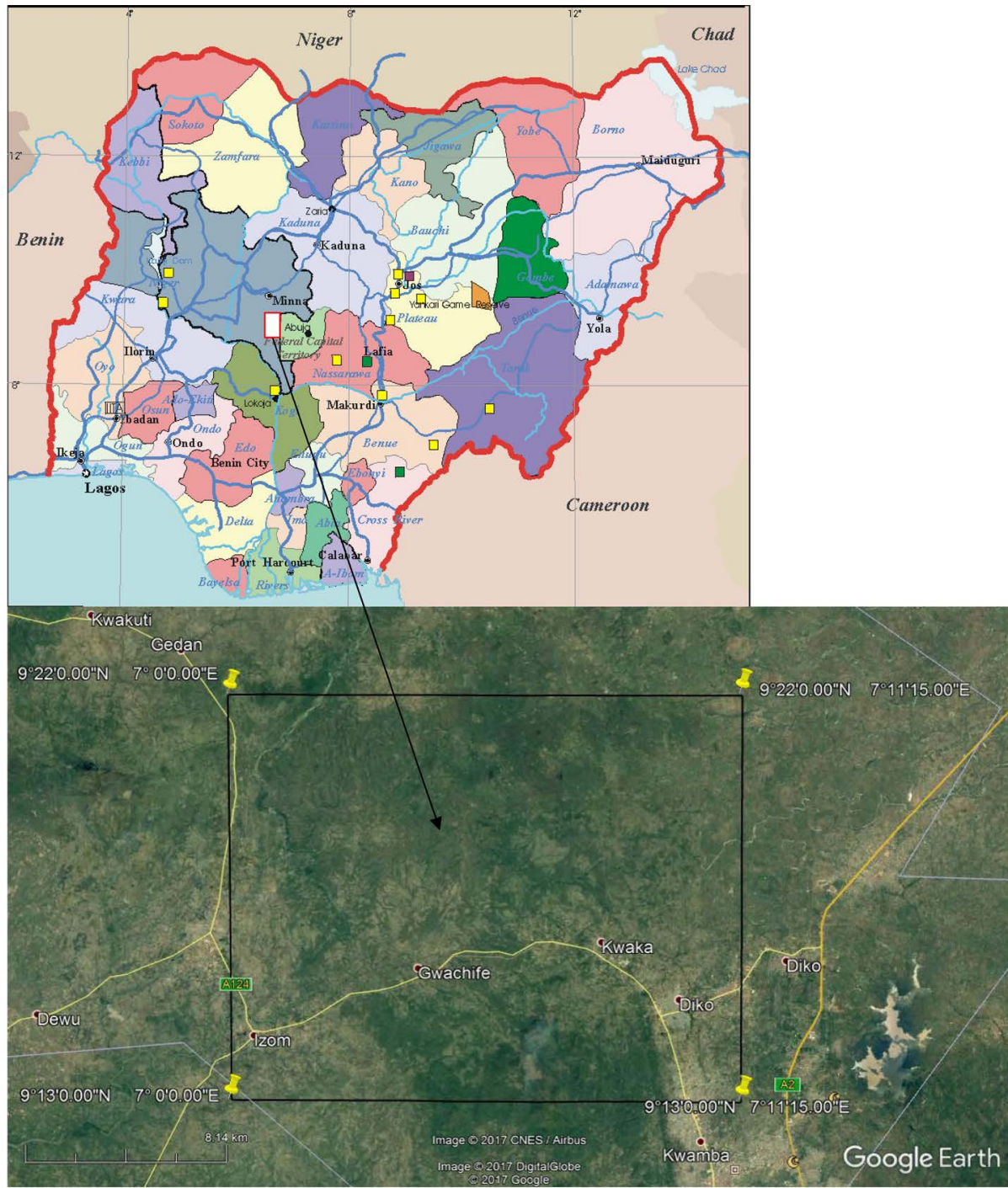

Figure 2. (A) Political map of Nigeria (Modified from Google Search), insert is the location of the study area; (B) The Google Earth extract of the exact location of the study area.

Macroscopic and microscopic (thin sections) examination of rock samples employing hand specimen examination and petrographic microscopic studies was conducted. Fractures within rocks and quartz minerals were observed carefully for gold occurrences. Veins and fractures within quartz veins were also looked at.

Structural features such as veins hosting quartz and other minerals were studied and their trends, sizes and orientations recorded.

\section{Results and Discussion}

\subsection{Mineralization}

Gold mineralization in the study area occurs in a variety of quartz veins and is generally related to the supracrustal schist belts (Figure 1). Some authors, e.g., (Amuda et al., 2013, Usman \& Ibrahim, 2017) also worked on such gold minera- 
lization that is restricted to quartz veins. Several locations of gold mineralization were detected in and around the Dikko area (Figure 2). The new gold occurrences associated with quartz veins were detected from geological studies (Figure 3 ) and conform to the general trend direction of N-S. This gold mineralization occurs along shear zones and parallel to the shear zones. These shear zones trend majorly in a N-S direction with few trending in a NE-SW direction and plunging NE.

\subsection{Petrography}

Hand specimen samples of rocks are presented here for the macroscopic identification (Plates 1-3).

Microscopic studies indicate that the amphibolite is composed of predominantly, the minerals hornblende and plagioclase feldspar, with minor amounts biotite and opaque minerals. It has very little amount of quartz with a weakly foliated or schistose (flaky) structure. The amphibolite schist is an amphibole schist metamorphic rock composed of opaque minerals, glaucophane, hornblende and minor actinolite and very little quartz. The gneiss has quartz and plagioclase which forms the light-colored bands of the rock, with mafic minerals including biotite, pyroxene and hornblende. Migmatite minerals in microscopic examination reveal quartz, plagioclase, amphibole and biotite. The pegmatite constitutes essentially quartz and the alkali feldspar with accessory muscovite, biotite and opaque minerals.
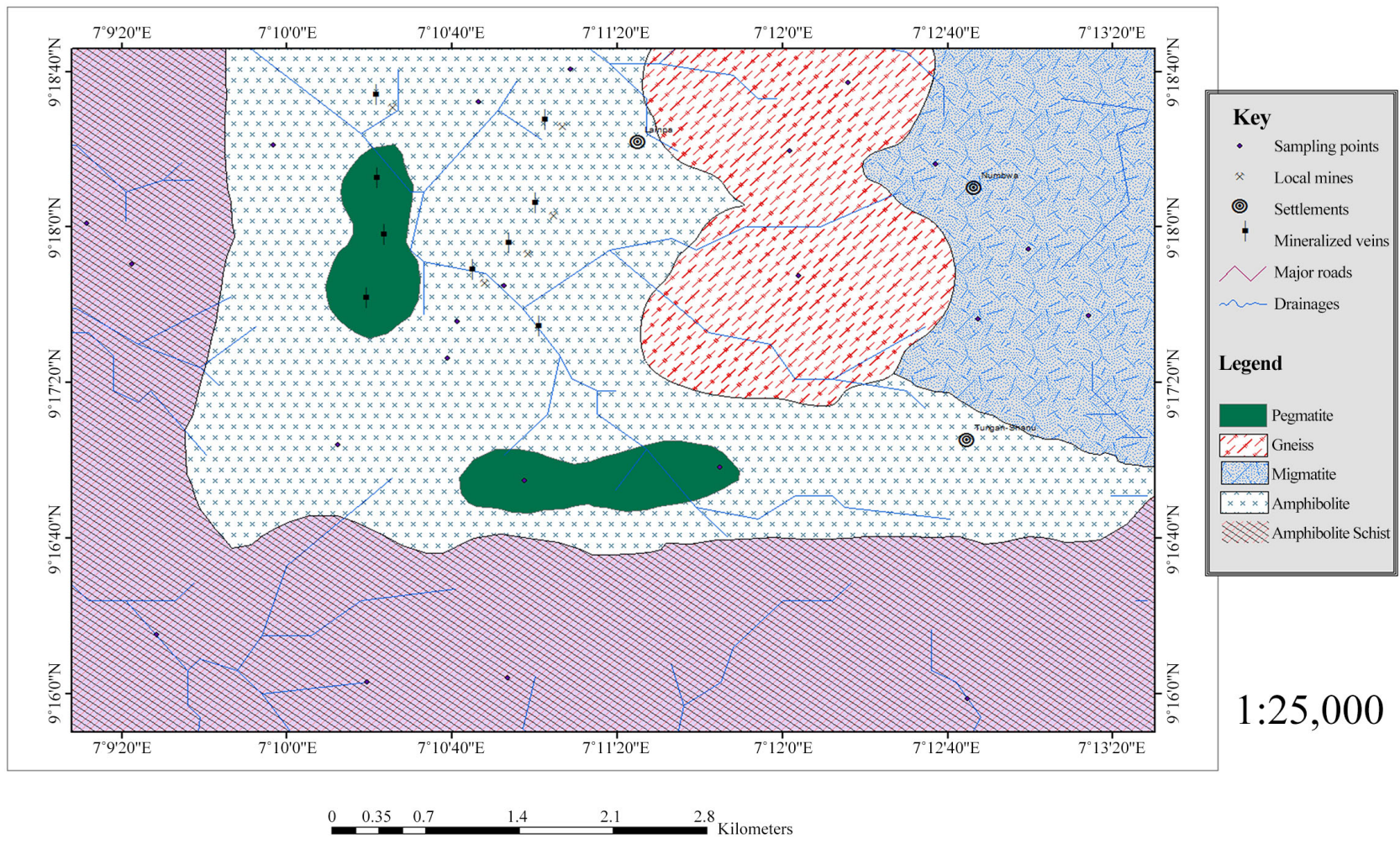

Figure 3. A simplified geological map of the study area (Dikko and Environs). 


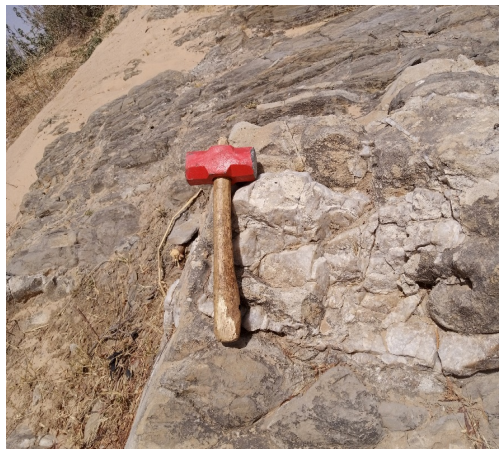

(a)

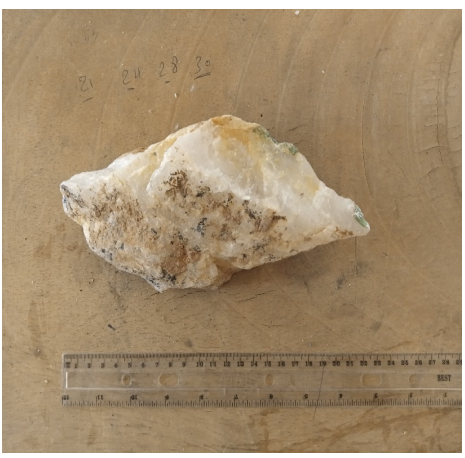

(b)

Plate 1. (a) Field sample of a quartz vein and (b) hand specimen sample of a quartz mineral.

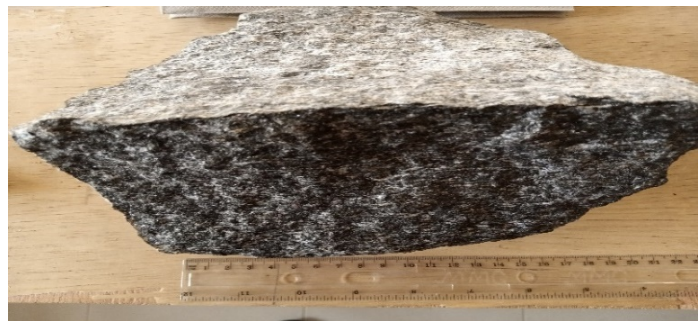

(a)

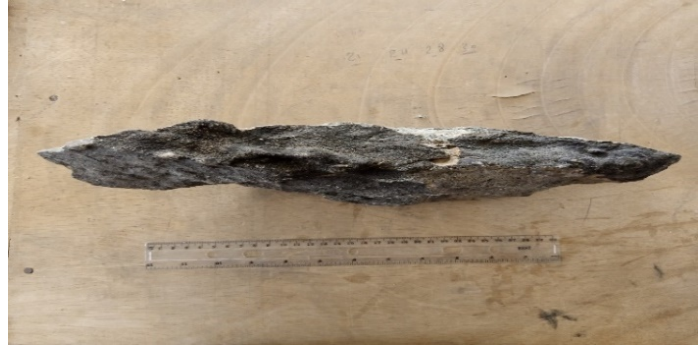

(b)

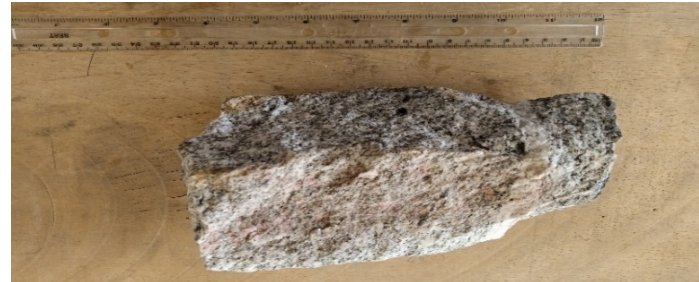

(c)

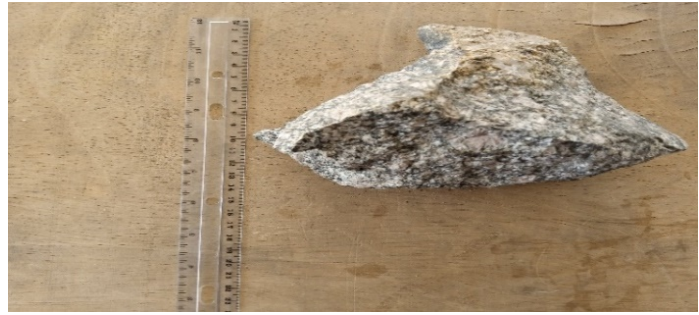

(d)

Plate 2. Hand Specimen samples of (a) Amphibolite, (b) Amphibolite Schist, (c) Gneiss and (d) Porphyroblastic Gneiss. 


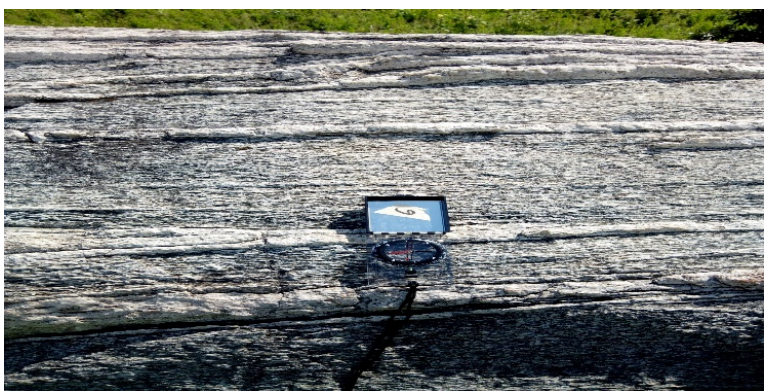

(a)

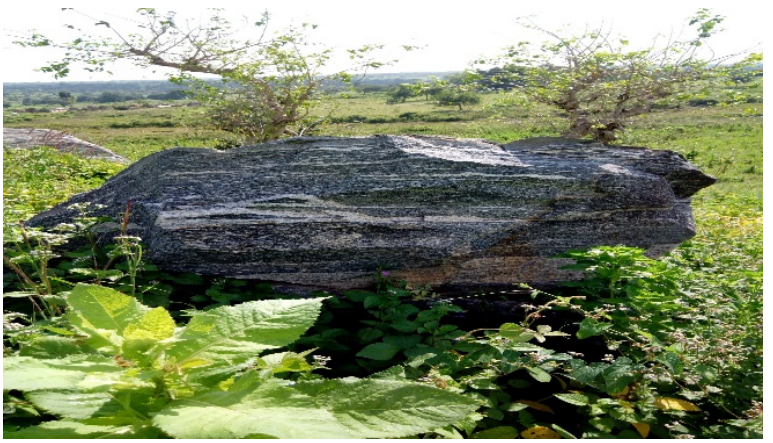

(b)

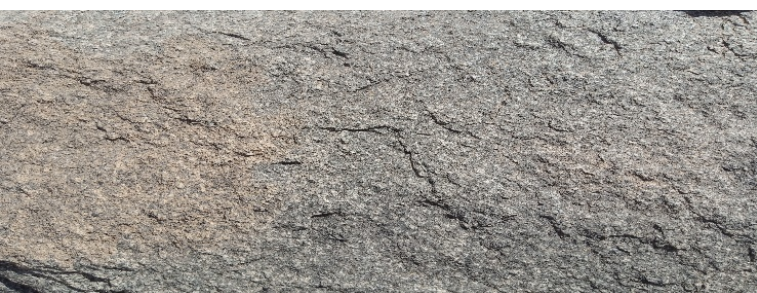

(c)

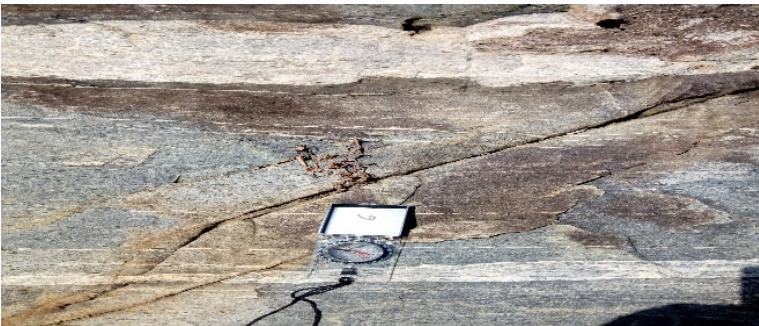

(d)

Plate 3. Field Samples of migmatite (a), (b) and (d), while (c) is an Amphibolite.

\subsection{Structures}

Many vein structures were measured and observed to be the structural barriers hosting the gold mineralization in the Dikko area. The amphibolites are the rocks hosting majority of the mineralization within quartz veins (Plate 4 and Plate 5). These structurally controlled gold mineralization hosted within quartz is represented in Plate 6.

The geological and tectonic setting of the Dikko deposits is critical to understanding their genesis, structural controls, and potential. As stated by Peters et 
al. (2002), tectonic and sedimentary environments, in relation to the metallogenic epochs of such deposits, allow the evaluation of the geological terrains in which they occur. Adama et al. (2019), discriminate directional trends towards gold mineralization. The gold mineralization of Dikko area occurs in a N-S trend direction.

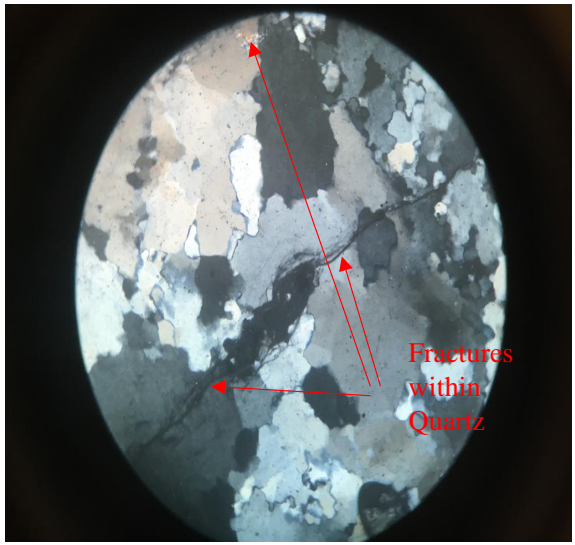

(a)

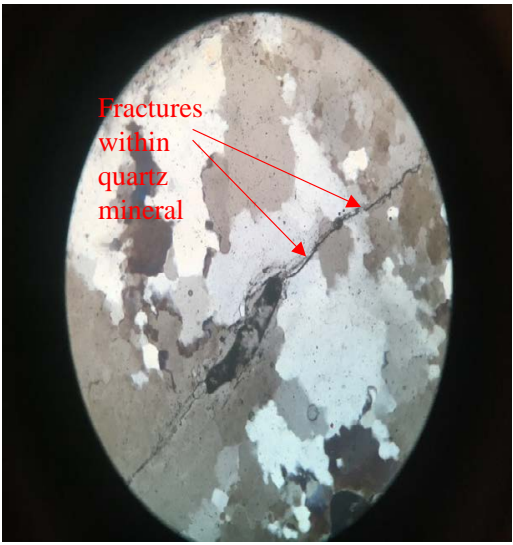

(b)

Plate 4. Photomicrographs ( $\mathrm{a}$ b) showing fractures or veins within Quartz minerals under cross polarized light.

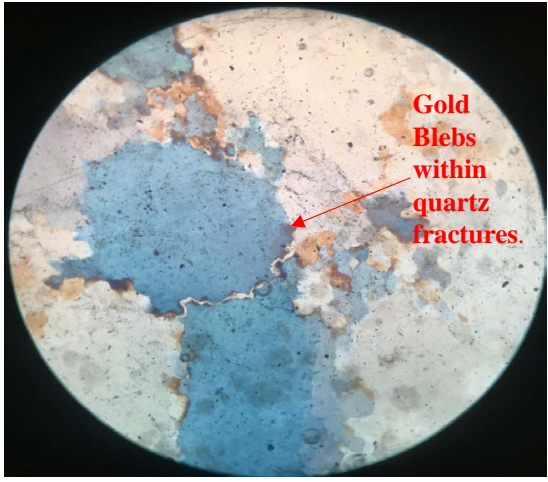

(a)

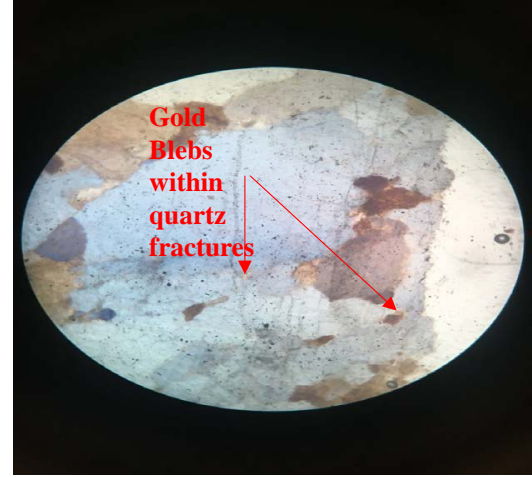

(b)

Plate 5. Photomicrograph ( $\mathrm{a} \& \mathrm{~b}$ ) showing Blebs of Gold within quartz fractures/veins under cross polarized light.

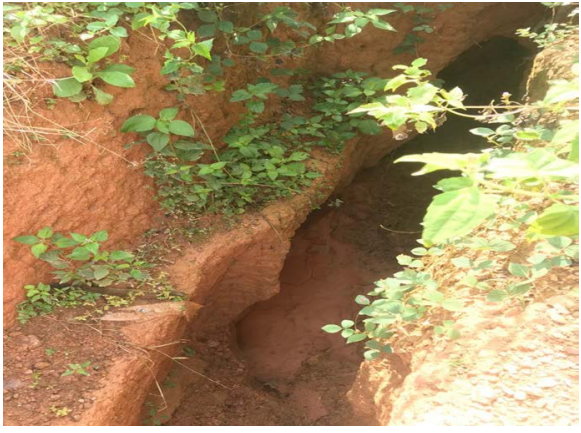

(a)

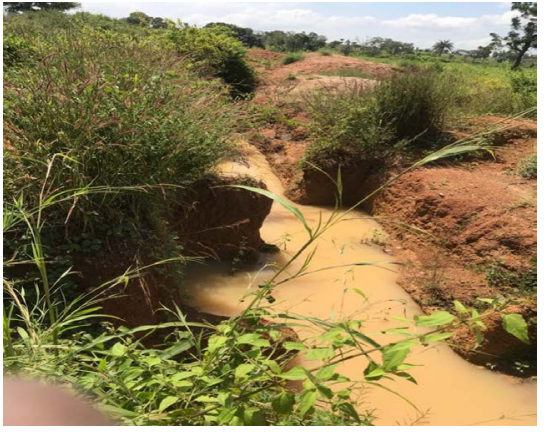

(b)

Plate 6. Showing veins striking N-S within the study area and hosting quartz minerals. 
From Plates 4-6 above, we conclude that the mineralization in this area therefore has lithological control. It appears mainly linked to the structures and therefore has structural control too. Several mineralized zones of the Dikko area have been controlled by these vein structures with a N-S steering structures. The interaction of hydrothermal fluids with the metamorphic rock could be one of the causes or formation of the respective gold mineralization.

\section{Conclusion}

This paper improves structural and lithological study of gold mineralization in the Dikko areas and surroundings. The analysis of the results of the work carried out here, allowed us to have an overview of the geology of these areas, which are located within the Pan-African Belt in Nigeria being part of the Benin-Nigeria (Dahomeyan) shield rocks of Proterozoic Formation. The lithological and structural studies carried out in these areas have demonstrated the relationship between structures and mineralization and/or lithology. The main characteristics of the gold mineralization in the area appear to indicate hydrothermal mineralization in connection with shear zones. The process of structural and lithological study in this work indicates two aspects. Firstly, the interpretation of the work carried out in the area showed that the mineralization is localized within the metamorphic amphibolite rock. Secondly, not all the amphibolite rocks of the area are affected by mineralization. It appears to be mainly linked to the structures and therefore has structural control.

\section{Acknowledgements}

The authors wish to acknowledge the TETFUND Board of Trustees for the year 2017 TETFUND RESEARCH PROJECTS (RP) INTERVENTION for this research work.

\section{Conflicts of Interest}

The authors declare no conflicts of interest regarding the publication of this paper.

\section{References}

Abubakar, Y. I. (2012). An Integrated Technique in Delineating Structures: A Case Study of the Kushaka Schist Belt Northwestern Nigeria. International Journal of Applied Science and Technology, 2, 164-173.

Adama, Y. K., Imen, H. N, Wajdi, B, Mohammed, H. I., Souleymane, S., \& Baco, T, (2019). Structural Controls of Gold Mineralization in Western Mali: Insights from Electromagnetic Data Analysis. International Workshop on Gravity, Electrical and Magnetic Methods and Their Applications, Xi'an, 19-22 May 2019.

Ajibade, A. C., \& Wright, J. B. (1989). The Togo-Benin-Nigeria Shield: Evidence of Crustal Aggregation in the Pan-African Belt. Tectonophysics, 165, 125-129.

https://doi.org/10.1016/0040-1951(89)90041-3

Ajibade, A. C., Woakes, M., \& Rahaman, M. A. (1987). Proterozoic Crustal Development 
in the Pan-African Regime of Nigeria. In Kroner, A., (Ed.), Proterozoic Lithospheric Evolution (pp. 259-271). Washington DC, USA: American Geophysical Union.

Amuda, A. K., Danbatta, U. A., \& Najime, T. (2013). Geology and Gold Mineralization around Kutceri Northwestern Nigeria. Journal of Applied Geology and Geophysics, 1, 18-24.

Bierlein, F. P., Arne, D. C., Mcknight, S., Lu, J., Reeves, S., Besanko, J., Marek, J., \& Cooke, D. (2000). Petrology and Geochemistry in Alteration Halos Associated with Mesothermal Gold Mineralization, Central Victoria, Australia. Economic Geology, 95, 283-312. https://doi.org/10.2113/gsecongeo.95.2.283

Craw, D., Windle, S. J., \& Angus, P. V. (1999). Gold Mineralization without Quartz Veins in a Ductile-Brittle Shear Zone, Macraes Mine, Otago Schist, New Zealand. Mineralium Deposita, 34, 382-394. https://doi.org/10.1007/s001260050211

Fitches, W. R., Ajibade, A. C., Egbuniwe, I. G., Holt, R. W., \& Wright, J. B. (1985). Late Proterozoic Schist Belts and Plutonism in NW Nigeria. Journal Geological Society London, 142, 319-337. https://doi.org/10.1144/gsigs.142.2.0319

Garba, I. (2000). Gold Prospects of the Nigeria Pan African Terrain of West Africa. Journal of Mining and Geology, 36, 123-135.

Garba, I. (2002). Late Pan-African Tectonics and Origin of Gold Mineralization and Rare-Metal Pegmatites in the Kushaka Schist Belt, Northwestern Nigeria. Nigerian Journal of Mining and Geology, 38, 1-12. https://doi.org/10.4314/jmg.v38i1.18768

Garba, I. (2003). Geochemical Characterization of Mesothermal Gold Mineralization in the Pan African (600 $\pm 150 \mathrm{Ma}$ ) Basement of Nigeria. Applied Earth Science, 112, 319-325. https://doi.org/10.1179/037174503225003143

Grant, N. K., Hickman, M., Burkholder, F. R., \& Powell, J. L. (1972). Kibaran Metamorphic Belt in the Pan-African Domain of West Africa. Nature Physical Sciences, 238, 90-91. https://doi.org/10.1038/physci238090a0

Kaufmann, H. (1988). Mineral Exploration along the Aqaba-Levant Structure by Use of TM-Data. International Journal of Remote Sensing, 9, 1639-1658. https://doi.org/10.1080/01431168808954966

Mitchell, M., Maw, L., Angus, P. V., \& Craw, D. (2006). The Macraes Gold Deposit in East Otago. Geology and Exploration of New Zealand Mineral Deposits. Mineralogy \& Metallogy Monogram, 25, 313-318.

Osman, A. (1995). The Use of Infrared Absorption Spectra and Neutron Activation Analysis in the Identification of Alteration Zones around Gold-Bearing Quartz Veins, Eastern Desert, Egypt. Bulletin of Ain Sham University, 33, 74-104.

Osman, A., \& Dardir, A. (1990). On the Mineralogy and Geochemistry of Some GoldBearing Quartz Veins in the Central Eastern Desert, Egypt and Their Altered Wall Rocks. Annual Geological Survey Egypt, 15, 17-25.

Peters, S. G., Huang, J., Li, Z., \& Jing, C. (2002). Introduction to and Classification of Sedimentary Rock-Hosted Au Deposits in P. R. China (U.S.G.S. Open File Report Series No. 2002-131, 60 p). Reston, VA: Geological Survey (U.S.). https://doi.org/10.3133/ofr2002131

Ramadan, T. M., \& Kontny, A. (2004). Mineralogical and Structural Characterization of Alteration Zones Detected by Orbital Remote Sensing at Shalatein District Area, SE Desert, Egypt. Journal of African Earth Sciences, 40, 89-99.

https://doi.org/10.1016/j.jafrearsci.2004.06.003

Ramadan, T. M., Abdelsalam, M. G., \& Stern, R. J. (2001). Mapping Gold-Bearing Massive Sulphide Deposits with Landsat TM and SIR-C/X SAR Imagery in the-Oprtoterozoic 
Allaqi Suture, SE Egypt. Journal of Photogrammetric Engineering and Remote Sensing, 67, 1-498.

Turner, D. C. (1983). Upper Proterozoic Schist in the Nigerian Sector of the Pan-African Province of West Africa. Precambrian Research, 21, 55-79. https://doi.org/10.1016/0301-9268(83)90005-0

Usman, M. A., \& Ibrahim, A. A. (2017). Petrography and Geochemistry of Rocks of Northern Part of Wonaka Schist Belt, Northwestern Nigeria. Nigerian Journal of Basic and Applied Science, 25, 87-99. https://doi.org/10.4314/njbas.v25i2.10

Woakes, M., \& Bafor, B. E. (1984). Primary Gold Mineralization in Nigeria. In: R. P. Foster (Ed.), GOLD' 82 The Geology Geochemistry and Genesis of Gold Deposits (pp. 661-671). Rotterdam: A. A. Balkema.

Wright. J. B., Hastings, D. A., Jones, W. B., \& Williams, H. R. (1985). Geology and Mineral Resources of West Africa. London: Allen and Unwin. 